\title{
In Vitro and In Vivo Effect of the Composition of Fucoxanthin with Porous Aluminum-Silicon Career on Cells
}

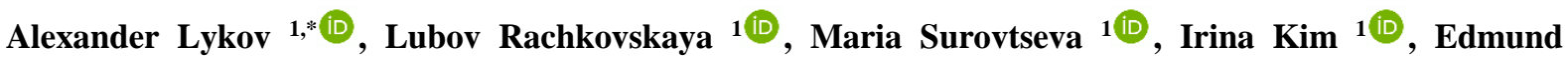

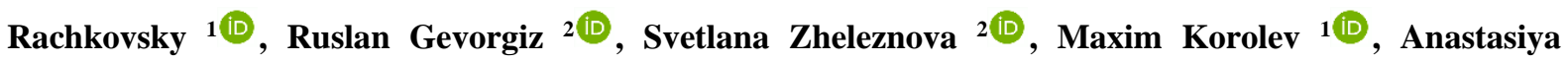

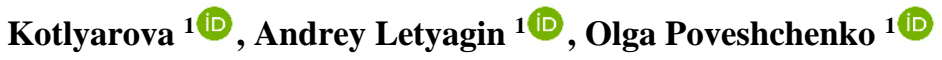 \\ 1 Research Institute of Clinical and Experimental Lymphology-Branch of the Institute of Cytology and Genetics Siberian \\ Branch of the Russian Academy of Sciences, Novosibirsk, Russia \\ 2 A.O. Kovalevsky Institute of Biology of the South Seas Russian Academy of Sciences, Sevastopol, Russia \\ * Correspondence: aplykov2@mail.ru;
}

Received: 19.08.2020; Revised: 9.09.2020; Accepted: 10.09.2020; Published: 13.09.2020

\begin{abstract}
Fucoxanthin natural carotenoid from seaweeds exhibits antioxidant properties. The paper analyzes the possibility of using fucoxanthin, immobilized on aluminum-silicon carrier particles, to assess the toxic effect on naïve or matured immune cells, enterocytes, Mesenchymal stem cells, and EA.Hy926 cell line. The proliferation, nitric oxide production, myeloperoxidase activity, and apoptosis of thymocytes and splenocytes of mice in vitro were studied. Proliferative capacity, nitric oxide production, and apoptosis rate of entreocytes, mesenchymal stem cells and EA.Hy926 cell line were investigated. It is shown that fucoxanthin immobilized on aluminum-silicon carrier particles increased the survival rate and proliferation of mature immunocytes (splenocytes) after 24 hours exposure and increased the survival rate of naïve immunocytes (thymocytes) when exposed 120 hours. On myeloperoxidase, the activity of immune cells is not affected by fucoxanthin immobilized on the carrier particles. Orally the administration of some samples of fucoxanthin immobilized on the carrier particles with different sizes, and dosage no have an adverse effect on jejunum enterocytes (proliferation and apoptosis). In vitro, all tested samples of fucoxanthin immobilized on the carrier particles with different sizes and dosage in common no have a toxic effect on jejunum enterocytes, human bone marrow mesenchymal stem cells, and EA.Hy926 cell line. The obtained results indicate that fucoxanthin, immobilized on particles of an aluminum-silicon carrier, does not have a toxic effect on mouse immunocytes and enterocytes, and human mesenchymal stem cells and EA.Hy92 cell line.
\end{abstract}

Keywords: Cylindrotheca closterium; fucoxanthin; $\gamma$-aluminum oxide; polydimethylsiloxane; immunocytes; enterocytes; mesenchymal stem cells; EA.Hy926.

(c) 2020 by the authors. This article is an open-access article distributed under the terms and conditions of the Creative Commons Attribution (CC BY) license (https://creativecommons.org/licenses/by/4.0/).

\section{Introduction}

Algae (brown or green seaweeds and diatoms) produced a wide range of natural carotenoids, such as astaxanthin, violaxanthin, fucoxanthin with antioxidant properties [1-4]. Fucoxanthin (Fx) a carotenoids which produced by brown alga and diatoms and has antioxidant, anticancer, anti-obesity, and antimicrobial action [5-7]. A carotenoids from algae are used as a food supplement or as an extracted powder from different brown microalgae or diatoms by ethanol. Hashimoto showed that single oral administration of Fx in mice in dosage 160 nanomolar leads to accumulation of it's metabolites fucoxanthinol and amarouciaxanthin A in adipose tissue within 24 hours, but Fx was not detected in tissues [8]. Only after 1-week https://biointerfaceresearch.com/ 
oral administration of Fx in mice tissues was detected Fx [8]. Administration of Fx in dosage 2 micromole has not altered lymphocytes [9]. Fx degradation depends on $\mathrm{pH}$, light, and temperature [10]. Orally administrated Fx incorporated by intestinal cells as fucoxanthinol [11]. Previously was demonstrated that composition on the bases of porous sorbent of gammaaluminum oxide with immobilized polydimethylsiloxane $\left(\gamma-\mathrm{Al}_{2} \mathrm{O}_{3} / \mathrm{PDMS}\right)$ upgrade of the pharmacological properties of sorbed on composition surface lithium citrate or melatonin (pharmacokinetics and safety) [12].

The aim of the study was to prepare composition on the bases of porous sorbent of $\gamma$ $\mathrm{Al}_{2} \mathrm{O}_{3} / \mathrm{PDMS}$ with immobilized $\mathrm{Fx} \quad\left(\gamma-\mathrm{Al}_{2} \mathrm{O}_{3} / \mathrm{PDMS} / \mathrm{Fx}\right)$ and analyzed the toxicity of $\gamma$ $\mathrm{Al}_{2} \mathrm{O}_{3} / \mathrm{PDMS} / \mathrm{Fx}$ in vitro and in vivo.

\section{Materials and Methods}

\subsection{Fucoxanthin extract preparation.}

The diatomic Alga Cylindrotheca closterium from the collection of microalga cultures of A.O. Kovalevsky Institute of Biology of the South Seas (Sevastopol, Russia) was used. The Cylindrotheca closterium culture was grown on a nutrient medium RS at a temperature of 20 $\pm 1{ }^{0} \mathrm{C}$, in the mode of cumulative cultivation in photobioreactors plane-parallel type with a working volume of $2 \mathrm{~L}$, a layer of $5 \mathrm{~cm}$, under continuous light, and bubbled with air $(0.5 \mathrm{~L}$ of air per $1 \mathrm{~L}$ of culture). After the accumulation of Fx up to $15-17 \mathrm{mg} / \mathrm{g}$ in the Cylindrotheca closterium biomass, the cells were deposited by centrifugation for 2-3 min at $2500 \mathrm{rpm}$ (1400 g). Thus, raw biomass with a high content of fucoxanthin was obtained. The biomass was washed with fresh water, then carried out the extraction of fucoxanthin. In brief, extracted powder of Cylindrotheca closterium by ethanol (2:1) at a temperature of $38-43{ }^{\circ} \mathrm{C}$ for 2 hours to obtained Fx rich extract, then distilled water was added to ethanol extract of Fx in a ratio of 1:1 at 24 hours and store in the dark, then centrifuged. The concentration of Fx in Cylindrotheca closterium was determined by thin-layer chromatography. The total ethanol extract of Fx was divided on chromatographic glass plates with a fixed layer of silica gel $0.5 \mathrm{~mm}$ thick in the acetone-hexane 3:7 system. The silica gel fraction containing Fx was extracted with ethanol, followed by centrifugation. The concentration of $\mathrm{Fx}\left(\mathrm{mg} / \mathrm{g}^{-1}\right)$ was determined spectrophotometrically at a wavelength of $442 \mathrm{~nm}$, followed by conversion to the dry mass of algae by the formula: $\mathrm{Fx}=\left(10 \times \mathrm{V}_{1} \times \mathrm{V}_{2} \times \mathrm{OD}_{442}\right) /\left(\mathrm{E}_{\mathrm{x}} \mathrm{V}_{3} \times \mathrm{B}\right)$, where $\mathrm{V}_{1}$, the volume of the eluate combined with plates, $\mathrm{mL}$; V2, the volume of sample extract, $\mathrm{mL}$; V3, volume aliquots deposited on the plate, mL; OD442 the optical density at a wavelength of $442 \mathrm{~nm}$; B, dry mass of algae, $g ; E=1280 \mathrm{~m}^{-1}$ is the specific extinction coefficient of Fx in ethanol.

2.2. Preparing of the composition on the bases of porous sorbent of gamma-aluminum oxide, polydimethylsiloxane, and fucoxanthin extract.

The porous sorbent of gamma-aluminum oxide $\left(\gamma-\mathrm{A}_{2}{ }_{2} \mathrm{O}_{3}\right)$ with particle sizes of 0.04 $\mathrm{mm}, 0.1 \mathrm{~mm}$, and $0.2-0.8 \mathrm{~mm}$ (Catalyst, Russia) was used. The polydimethylsiloxane $\left(\left(\mathrm{CH}_{3}\right)_{3}-\right.$ $\mathrm{Si}-\mathrm{O}-\left(\mathrm{Si}\left(\mathrm{CH}_{3}\right)_{2}-\mathrm{O}\right)_{\mathrm{n}}-\mathrm{Si}\left(\mathrm{CH}_{3}\right)_{2}-\mathrm{O}-\mathrm{Si}\left(\mathrm{CH}_{3}\right)_{3}$, PDMS, Penta, Russia) with a molecular weight of 18000-19000 and particle diameter $60 \mu \mathrm{m}$ was used in the form of an aqueous emulsion. The immobilization of PDMS on $\gamma-\mathrm{A}_{2} \mathrm{O}_{3}$ surface was done in the aqueous phase at room temperature. Then obtained carrier $\left(\gamma-\mathrm{A}_{2}{ }_{2} \mathrm{O}_{3} / \mathrm{PDMS}\right)$ was dried and subjected to short-term temperature up to $200{ }^{0} \mathrm{C}$. The composition of the $\gamma-\mathrm{A}_{2}{ }_{2} \mathrm{O}_{3} / \mathrm{PDMS} / \mathrm{Fx}$ was obtained by immobilization by physical adsorption on the surface of porous sorbent aluminum oxide of a 
mixture of an aqueous emulsion of polydimethylsiloxane and an ethanol extract of Fx at room temperature. The finished composition of the $\gamma-\mathrm{A}_{2}{ }_{2} \mathrm{O}_{3} / \mathrm{PDMS} / \mathrm{Fx}$ was represented by particles of different granulometric composition of the sorption material based on aluminum oxide and polydimethylsiloxane, on the surface of which fucoxanthin is immobilized in the amount of $0.074-0.22 \mathrm{mg} / \mathrm{g}$ of the sorbent.

\subsection{Characterization of $\gamma-\mathrm{Al}_{2} \mathrm{O}_{3} / \mathrm{PDMS}$ carrier properties.}

The content of silica in the composition of the emulsion and the carrier was determined by atomic emission spectrometry with inductive-coupled plasma on a spectrometer Baird (Netherlands). The distribution of PDMS in the pore space of $\gamma-\mathrm{Al}_{2} \mathrm{O}_{3}$ was investigated by the method of low-temperature nitrogen adsorption $\left(77.4{ }^{0} \mathrm{~K}\right)$ on the ASAP-2400 and on DigiSorb-2600 (Micrometrics, USA), the pore size distribution was calculated by the BarrettJoyner-Halend method. The specific surface of carrier samples was determined by the BET method, and the pore size and volume were determined from nitrogen sorption isotherms. The bulk density and the flowability of the obtained samples were determined.

\subsection{Animals.}

All experiments were performed with the prior approval of the Ethics Committee of Research Institute of Clinical and Experimental Lymphology-Branch of the Institute of Cytology and Genetics RAS were conducted in accordance with the principles and guidelines of the Declaration of Helsinki.

Female CBA f mice (25-30 g) were obtained from a vivarium at the Institute of Cytology and Genetics (Novosibirsk, Russia), and maintained under standard conditions (temperature $20-25{ }^{\circ} \mathrm{C}, 12$ hours light/dark cycle), and received water and food ad libitum. The ethanol extract of Fx in dosage $9 \mu \mathrm{g} /$ mouse in $0.5 \mathrm{~mL}$ of $0.9 \% \mathrm{NaCl}$ solution, and $1 \mathrm{mg} / \mathrm{mouse}$ of $\gamma-\mathrm{A}_{2} \mathrm{O}_{3} / \mathrm{PDMS}$ with size $0.04 \mathrm{~mm}$ and $0.1 \mathrm{~mm}$ in $0.5 \mathrm{~mL}$ of $0.9 \% \mathrm{NaCl}$ solution, and composition sample $16,17,18$ and 19 in dosage $1 \mathrm{mg} /$ mouse in $0.5 \mathrm{~mL}$ of $0.9 \% \mathrm{NaCl}$ solution was administered orally in experimental groups, and $0.5 \mathrm{~mL}$ of $0.9 \% \mathrm{NaCl}$ solution in control group ( 3 mouse in each group) to examined toxicity. Then 24 hours late, animals were sacrificed by cervical dislocation, thymus, and spleen, and jejunum was remote.

\subsection{Cells}

The spleens and thymus were extracted, combed, and the resulting cell suspension filtered through a 60- $\mu$ m nylon mesh (TETKO, USA). Then, cells were twice washed in PBS, centrifuged at 1,000 rpm for 5 minutes, and then resuspended in medium RPMI1640 (Biolot, Russia) with the addition of $80 \mu \mathrm{g} / \mathrm{mL}$ gentamicin sulfate, $2 \mathrm{mM}$ L-glutamine, 5 millimol HEPES-buffer, and $10 \%$ FCS at a concentration $10^{6}$ cells $/ \mathrm{mL}$.

The jejunum after removal was placed in iced saline, rinsed three times with $0.9 \% \mathrm{NaCl}$ solution, then rinsed jejunum segments are incubated with $2 \mathrm{~mL}$ of $0.25 \%$ trypsin solution and $0.02 \%$ EDTA solution for 15 minutes at $37{ }^{\circ} \mathrm{C}$ to isolated villus enterocytes, then isolation solution was collected and centrifuged at 1,000 rpm for 5 minutes. The pellet was twice washed with $0.9 \% \mathrm{NaCl}$ solution and then resuspended in medium DMEM with the addition of 80 $\mu \mathrm{g} / \mathrm{mL}$ gentamicin sulfate, $2 \mathrm{mM}$ L-glutamine, 5 millimol HEPES-buffer, and 10\% FCS at a concentration $10^{6}$ cells $/ \mathrm{mL}$. 
Bone marrow mesenchymal stem cells (MSCs) was obtained from patients with ischemic heart disease with diffuse and distal coronary arterial disease [13]. In brief, bone marrow mononuclear cells (MNCs) were isolated from bone marrow aspirate on Ficoll-Paque density gradient $(\rho=1,077 \mathrm{~g} / \mathrm{L})$ by centrifugation, then washed three times with phosphate buffer saline, and were placed in plastic flasks (TPP, Switzerland) in culture medium DMEM with the addition of $80 \mu \mathrm{g} / \mathrm{mL}$ gentamicin sulfate, $2 \mathrm{mML}$-glutamine, and $10 \%$ fetal calf serum (FCS, Hyclone, USA) at a concentration of $10^{6}$ cells $/ \mathrm{cm}^{2}$, and grown at $37{ }^{0} \mathrm{C}$ in an atmosphere of 5\% $\mathrm{CO}_{2} / 95 \%$ air for 72 hours. Further, the non-adhered fraction of MNCs was removed, and a fresh medium was added, and cells were cultivated until a confluent monolayer of 80$90 \%$ was obtained. The culture medium was changed every 3-4 days. Cells were transplanted by removal of cells with $0.25 \%$ trypsin solution and $0.02 \%$ EDTA solution. The cells from the 4-th passage were used in the experiments.

EA.Hy926 cells were grown to $80-90 \%$ confluence in plastic flasks in culture medium DMEM/F12 with the addition of $80 \mu \mathrm{g} / \mathrm{mL}$ gentamicin sulfate, $2 \mathrm{mM} \mathrm{L-glutamine,} \mathrm{and} 10 \%$ FCS in an atmosphere of $5 \% \mathrm{CO}_{2} / 95 \%$ air.

\subsection{MTT assay.}

Splenocytes, thymocytes, and enterocytes from untreated CBA mice, MSCs, and EA.Hy926 104/wells proliferative capacity with or without of tested samples in culture medium DMEM or DMEM/F12 with the addition of $80 \mu \mathrm{g} / \mathrm{mL}$ gentamicin sulfate, $2 \mathrm{mM}$ L-glutamine, and $10 \%$ FCS were detected by 3-(4,5-dimethylyhiazol-2-yl)-2,5-diphenyltetrazolium bromide (Merck, USA) assay (MTT assay).

\subsection{Nitrite production.}

Nitric oxide (NO) production by treated and untreated with of tested samples of CBA mice splenocytes, thymocytes, enterocytes, and MSCs, and EA.Hy926 was measured using Griess reagent for nitrite determination (Merck, USA). The levels of NO were calculated using a sodium nitrite standard curve.

\subsection{Acridine orangelethidium bromide staining.}

The $10^{4}$ enterocytes from untreated and treated with Fx mice were stained with acridine orange and ethidium bromide solutions $(100 \mu \mathrm{g} / \mathrm{mL}$, Merck, USA) at 5 minutes, then twice washed with $0.9 \% \mathrm{NaCl}$ solution and observed under an Axio Observer Z1 microscope (Zeiss, Germany) [14].

\subsection{Myeloperoxidase (MPO) activity.}

MPO activity of treated and untreated with tested samples of the splenocytes and the thymocytes was detected by a mixture of 1 part of $0.6 \%$ solution of benzidine (Merck, USA) based on a $96 \%$ solution of $\mathrm{C}_{2} \mathrm{H}_{5} \mathrm{OH}$, and 2.5 parts of a mixture of $0.25 \mathrm{ml}$ of $33.4 \% \mathrm{H}_{2} \mathrm{O}_{2}$ (Merck, USA) of $2.25 \mathrm{ml}$ of $70 \%$ solution of $\mathrm{C}_{2} \mathrm{H}_{5} \mathrm{OH}$ [15]. Viability and proliferation activity in the presence of $\gamma-\mathrm{A}_{2} \mathrm{O}_{3} / \mathrm{PDMS} / \mathrm{Fx}$ in dosage $0 \mu \mathrm{g}$ and $0.057 \mu \mathrm{g}$ was detected after $24 \mathrm{~h}$ (short-term exposure) and $120 \mathrm{~h}$ (long-term exposure). 


\subsection{Statistical analysis.}

Data were analyzed by the Statistica 10.0 for Windows. In this study, the normality of the distribution was determined by the w-Shapiro-Wilkes criterion, in tables, the obtained data were presented as mean \pm standard deviation (SD), the data were analyzed by one-way analysis of variance (ANOVA) with a Bonferroni correction (Bonferroni post hoc test) to analyze differences between groups. If p-values were less than 0.05 , it was considered statistically significant.

\section{Results and Discussion}

\subsection{Characterization of $\gamma-\mathrm{Al}_{2} \mathrm{O}_{3} / \mathrm{PDMS} / \mathrm{Fx}$.}

The prepared samples of $\gamma-\mathrm{Al}_{2} \mathrm{O}_{3} / \mathrm{PDMS} / \mathrm{Fx}$ have good organoleptic properties; they are round yellow granules with a particle size of $0.04 \mathrm{~mm}, 0.1 \mathrm{~mm}$, and $0.2-0.8 \mathrm{~mm}$, and with a developed meso- and macroporous structure, and with a predominant size of 10-100 nm, and with PDMS 0.4\%, and with a hydrophilic-hydrophobic chemical nature of the surface, and with acceptable technological parameters, high mechanical strength, and good flowability. The phase composition of the obtained carriers $\gamma-\mathrm{Al}_{2} \mathrm{O}_{3} / \mathrm{PDMS}$ corresponds to the phase composition of $\gamma-\mathrm{A}_{2} \mathrm{O}_{3}$, which is characterized by clear lattice parameters 7.908 , and dispersion D (primary particle size) 50 angstroms (figure 1). The study of the distribution of PDMS in the pore space allowed us to estimate the size of the polymer fragments in the pore space of $\gamma$-aluminum oxide about $2-5 \mathrm{~nm}$, which indicates the high dispersion of polymer particles on the surface of $\gamma$-aluminum oxide.

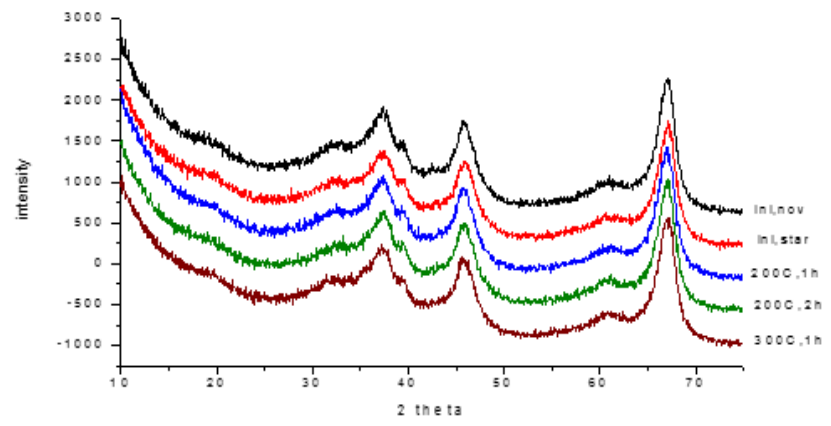

Figure 1. Diffractograms of a series of samples of gamma-aluminum oxide. On the axis of ordinates - the peak of intensity; on the axis of abscissa - angel $2 \Theta$ ( 2 theta); ini. nov and ini. star - two original batches from the manufacturer. Burning batch ini. nov at $200{ }^{\circ} \mathrm{C}$ for 1 and 2 hours, and at $300{ }^{\circ} \mathrm{C}$ for 1 hour, retains the structure of the original sample.

Table 1. Characterization of the $\gamma-\mathrm{A}_{2} \mathrm{O}_{3} / \mathrm{PDMS} / \mathrm{Fx}$ composition.

\begin{tabular}{l|l|l|l|l}
\hline Sample & $\begin{array}{l}\boldsymbol{\gamma}-\mathbf{A 1}_{2} \mathbf{O}_{3} / \mathbf{P D M S} / \mathbf{F x} \\
\text { particle size, } \mathbf{~ m m}\end{array}$ & $\mathbf{S}, \mathbf{~ m}^{\mathbf{2}} / \mathbf{g}$ & $\mathbf{V}, \mathbf{c m}^{\mathbf{3}} / \mathbf{g}$ & $\mathbf{F x}, \mathbf{m g} / \mathbf{g}$ \\
\hline $\mathrm{N} 14$ & 0.1 & 157.4 & 0.26 & 0.074 \\
\hline $\mathrm{N} 15$ & 0.1 & 157.4 & 0.26 & 0.148 \\
\hline $\mathrm{N} 16$ & 0.1 & 157.4 & 0.26 & 0.22 \\
\hline $\mathrm{N} 17$ & 98.0 & 0.2 & 0.074 \\
\hline $\mathrm{N} 18$ & 0.04 & 98.0 & 0.2 & 0.148 \\
\hline $\mathrm{N} 19$ & 0.04 & 98.0 & 0.2 & 0.22 \\
\hline $\mathrm{N} 20$ & 0.04 & 198.0 & 0.34 & 0.074 \\
\hline $\mathrm{N} 21$ & $0.2-0.8$ & 198.0 & 0.34 & 0.148 \\
\hline $\mathrm{N} 22$ & $0.2-0.8$ & 198.0 & 0.34 & 0.22 \\
\hline
\end{tabular}

Note: $\gamma$ - $\mathrm{A}_{2} \mathrm{O}_{3} / \mathrm{PDMS} / \mathrm{Fx}$ - particles of $\gamma$-aluminum oxide with a polydimethylsiloxane and immobilized fucoxanthin, $\mathrm{S}$ - specific surface of the particles, $\mathrm{V}$ - pore volume of the particles. 
The values of the specific surface area and pore volume of the $\gamma-\mathrm{A}_{2}{ }_{2} \mathrm{O}_{3} / \mathrm{PDMS}$, and $\gamma$ $\mathrm{A} 12_{2} \mathrm{O}_{3} / \mathrm{PDMS} / \mathrm{Fx}$ was similar (Table 1). Fx was evenly distributed over the surface of the particles. This fact singed that during Fx, immobilization has no clogging carrier pore.

\subsection{Effects of the $\gamma-\mathrm{Al}_{2} \mathrm{O}_{3} / \mathrm{PDMS} / \mathrm{Fx}$ composition on splenocytes and thymocytes.}

First, we have studied the influence of $\gamma-\mathrm{A}_{2} \mathrm{O}_{3} / \mathrm{PDMS} / \mathrm{Fx}$ composition based on 0.1 $\mathrm{mm}$ particles of the $\gamma-\mathrm{A}_{2} \mathrm{O}_{3} / \mathrm{PDMS}$ and immobilized $0.057 \mathrm{mg}$ of Fx on $1 \mathrm{~g}$ of the $\gamma$ $\mathrm{A}_{1} \mathrm{O}_{3} / \mathrm{PDMS}$ on splenocytes and thymocytes function from CBA mice (Table 2). We have estimated that ethanol extract of the Fx immobilized on porous sorbent surface after $24 \mathrm{~h}$ exposition in vitro with splenocytes and thymocytes of CBA mice significantly increased splenocytes proliferative activity and not have an influenced on thymocytes proliferation compared with control $(\mathrm{p}<0.05)$. At the same time, long-term exposition of the splenocytes and thymocytes with $\gamma-\mathrm{A}_{2} \mathrm{O}_{3} / \mathrm{PDMS} / \mathrm{Fx}$ possess decreased proliferation of splenocyte and increased thymocytes proliferative capacity $(\mathrm{p}<0.05)$. At the same time, NO production by splenocytes and thymocytes in the presence of $\gamma$-A1 ${ }_{2} \mathrm{O}_{3} / \mathrm{PDMS} / \mathrm{Fx}$ composition during $24 \mathrm{~h}$ and $120 \mathrm{~h}$ increased compared with control $(\mathrm{p}<0.05)$. We have not found significant changes in MPO activity of the splenocytes and thymocytes of CBA mice compared with control $(\mathrm{p}>0.05)$.

Table 2. Effect of $\gamma-\mathrm{Al}_{2} \mathrm{O}_{3} / \mathrm{PDMS} / \mathrm{Fx}$ based on $0.1 \mathrm{~mm}$ particles on splenocytes and thymocytes functions $(\mathrm{M} \pm \mathrm{SD})$.

\begin{tabular}{|c|c|c|c|c|c|}
\hline Parameters & Basal & $\begin{array}{l}96 \% \quad \mathrm{C}_{2} \mathrm{H}_{5} \mathrm{OH}, \\
10 \mu \mathrm{L} / \text { well }\end{array}$ & $\begin{array}{ll}0.1 \quad \text { mm } & \gamma- \\
\mathrm{A1}_{2} \mathrm{O}_{3} / \mathrm{PDMS}, \\
\mathrm{mg} / \mathrm{mL}\end{array}$ & $\begin{array}{ll}\text { Fx, } & 0.057 \\
\mu \mathrm{g} / \mathrm{mL} & \end{array}$ & $\begin{array}{l}\gamma-\mathrm{A1}_{2} \mathrm{O}_{3} / \mathrm{PDMS} / \mathrm{Fx}, 1 \\
\mathrm{mg} / \mathrm{mL}\end{array}$ \\
\hline \multicolumn{6}{|c|}{ Proliferation after 24 hours exposition (OD) } \\
\hline Splenocytes & $1.37 \pm 0.23$ & $1.43 \pm 0.41$ & $1.5 \pm 0.33$ & $1.64 \pm 0.41$ & $1.79 \pm 0.33 * \dagger$ \\
\hline Thymocytes & $0.69 \pm 0.21$ & $0.46 \pm 0.08^{*}$ & $0.65 \pm 0.27$ & $0.68 \pm 0.17$ & $0.8 \pm 0.33$ \\
\hline \multicolumn{6}{|c|}{ NO production after 24 hours exposition (micromole/mL) } \\
\hline Splenocytes & $8.39 \pm 0.6$ & $7.87 \pm 0.53$ & $10.64 \pm 0.65$ & $10.57 \pm 1.06 *$ & $9.36 \pm 1.03 *+\dagger$ \\
\hline Thymocytes & $8.62 \pm 0.59$ & $7.72 \pm 0.75^{*}$ & $12.1 \pm 0.53 *$ & $10.17 \pm 1.01^{*}$ & $9.24 \pm 1.07+t$ \\
\hline \multicolumn{6}{|c|}{ Proliferation after 120 hours exposition (OD) } \\
\hline Splenocytes & $0.9 \pm 0.19$ & $0.68 \pm 0.09^{*}$ & $0.7 \pm 0.13$ & $1.05 \pm 0.29 *$ & $0.81 \pm 0.1 \dagger+$ \\
\hline Thymocytes & $0.55 \pm 0.07$ & $0.66 \pm 0.12$ & $0.6 \pm 0.17$ & $0.64 \pm 0.13$ & $0.84 \pm 0.32 *+\dagger$ \\
\hline \multicolumn{6}{|c|}{ NO production after 120 hours exposition (micromole/mL) } \\
\hline Splenocytes & $6.97 \pm 0.79$ & $7.69 \pm 1.04$ & $9.41 \pm 0.78 *$ & $8.58 \pm 0.74 *$ & $8.46 \pm 0.74 * \dagger$ \\
\hline Thymocytes & $6.95 \pm 0.92$ & $6.75 \pm 1.0$ & $9.28 \pm 0.78 *$ & $8.21 \pm 0.68^{*}$ & $8.83 \pm 0.9 *$ \\
\hline \multicolumn{6}{|c|}{ MPO activity after 120 hours exposition (OD) } \\
\hline Splenocytes & $1.51 \pm 0.31$ & $1.71 \pm 0.34$ & $1.62 \pm 0.31$ & $1.58 \pm 0.36$ & $1.7 \pm 0.33$ \\
\hline Thymocytes & $1.07 \pm 0.11$ & $1.11 \pm 0.03$ & $0.96 \pm 0.08$ & $1.18 \pm 0.11$ & $1.15 \pm 0.13 \dagger$ \\
\hline
\end{tabular}

Table 3. Effect of oral administration of $\gamma-\mathrm{Al}_{2} \mathrm{O}_{3} / \mathrm{PDMS} / \mathrm{Fx}$ on enterocytes from jejunum proliferation $(\mathrm{M} \pm \mathrm{SD})$.

\begin{tabular}{|c|c|}
\hline Parameters & OD \\
\hline Basal & $0.52 \pm 0.02$ \\
\hline Fx, $18 \mathrm{mg} / \mathrm{mouse}$ & $0.42 \pm 0.01 *$ \\
\hline $0.04 \mathrm{~mm} \gamma-\mathrm{A} 1_{2} \mathrm{O}_{3} / \mathrm{PDMS}, 1 \mathrm{mg} / \mathrm{mL}$ & $0.47 \pm 0.01 * \dagger$ \\
\hline $0.1 \mathrm{~mm} \gamma-\mathrm{Al}_{2} \mathrm{O}_{3} / \mathrm{PDMS}, 1 \mathrm{mg} / \mathrm{mL}$ & $0.88 \pm 0.04 *+\dagger$ \\
\hline $\mathrm{N} 16,1 \mathrm{mg} / \mathrm{mL}$ & $0.45 \pm 0.02 *+\dagger$ \\
\hline $\mathrm{N} 17,1 \mathrm{mg} / \mathrm{mL}$ & $0.52 \pm 0.01+\dagger^{\bullet}$ \\
\hline $\mathrm{N} 18,1 \mathrm{mg} / \mathrm{mL}$ & $0.57 \pm 0.01 * \dagger+\bullet \theta$ \\
\hline $\mathrm{N} 19,1 \mathrm{mg} / \mathrm{mL}$ & $0.64 \pm 0.02 *+a \bullet \Theta \diamond$ \\
\hline
\end{tabular}

Note: Fx - ethanol extract of fucoxanthin. $\mathrm{p}<0.05 *$ - with basal, $\uparrow$ - with Fx, $\$$ - with $0.04 \mathrm{~mm} \gamma-\mathrm{A}_{2} \mathrm{O}_{3} / \mathrm{PDMS}, \mathrm{a}-$ with $0.1 \mathrm{~mm} \gamma$-A $1_{2} \mathrm{O}_{3} / \mathrm{PDMS}$, - - with N16, $\mathrm{O}$ - with N 17, $\diamond$ - with N18. 
While ethanol extract of the Fx in dosage $18 \mathrm{mg} / \mathrm{mouse}$ and $0.04 \mathrm{~mm}$ porous sorbent also decreased enterocytes proliferative capacity $(\mathrm{p}<0.05)$. At the same time, $0.1 \mathrm{~mm}$ porous sorbent on the bases of $\gamma-\mathrm{A}_{2}{ }_{2} \mathrm{O}_{3} / \mathrm{PDMS}$ stimulated the proliferation of enterocytes $(\mathrm{p}<0.05)$.

Screening of the different samples of $\gamma-\mathrm{A}_{1}{ }_{2} \mathrm{O}_{3} / \mathrm{PDMS} / \mathrm{Fx}$ composition based on 0.04 $\mathrm{mm}, 0.1 \mathrm{~mm}$, and $0.2-0.8 \mathrm{~mm}$ with Fx dosage range from $0.074 \mathrm{mg} / \mathrm{g}$ to $0.22 \mathrm{mg} / \mathrm{g}$ on MSCs, EA.Hy926, and enterocyte proliferation and NO production revealed a significantly decreased proliferation of the MSCs (Table 4). While samples of $\gamma-\mathrm{A}_{2} \mathrm{O}_{3} / \mathrm{PDMS} / \mathrm{Fx}$ composition significantly increased proliferative activity of EA.Hy926, and have a controversy influence on enterocytes' proliferation.

Table 4. Effect of $\gamma-\mathrm{A}_{2} \mathrm{O}_{3} / \mathrm{PDMS} / \mathrm{Fx}$ composition on mesenchymal stem cells (MSCs), endothelial cell line EA.Hy926 (EA.Hy926), and enterocytes from jejunum (En) proliferation (M+SD, OD).

\begin{tabular}{l|l|l|l}
\hline Parameters & MSCs & EA.Hy926 & En \\
\hline Basal & $0.71 \pm 0.03$ & $0.6 \pm 0.01$ & $0.52 \pm 0.01$ \\
\hline $\begin{array}{l}0.04 \mathrm{~mm} \gamma-\mathrm{A}_{2} \mathrm{O}_{3} / \mathrm{PDMS}, 1 \\
\mathrm{mg} / \mathrm{mL}\end{array}$ & $0.76 \pm 0.1$ & $0.64 \pm 0.02^{*}$ & $0.52 \pm 0.01$ \\
\hline $\begin{array}{l}0.1 \mathrm{~mm} \gamma-\mathrm{A}_{2} \mathrm{O}_{3} / \mathrm{PDMS}, 1 \\
\mathrm{mg} / \mathrm{mL}\end{array}$ & $0.49 \pm 0.01^{*}$ & $0.59 \pm 0.02$ & $0.58 \pm 0.09$ \\
\hline $\begin{array}{l}0.2-0.8 \\
\mathrm{~A} 1{ }_{2} \mathrm{O} / \mathrm{PDMS}, 1 \mathrm{mg} / \mathrm{mL}\end{array}$ & $0.52 \pm 0.02^{*}$ & $0.64 \pm 0.09$ & \\
\hline $\mathrm{Fx}, 0.000074 \mathrm{mg} / \mathrm{mL}$ & $0.8 \pm 0.04^{*}$ & & $0.53 \pm 0.03$ \\
\hline $\mathrm{Fx}, 0.000148 \mathrm{mg} / \mathrm{mL}$ & $0.83 \pm 0.03^{*}$ & $0.58 \pm 0.04$ & $0.53 \pm 0.03$ \\
\hline $\mathrm{Fx}, 0.00022 \mathrm{mg} / \mathrm{mL}$ & $0.85 \pm 0.18$ & $0.75 \pm 0.03^{*}$ & $0.61 \pm 0.04^{*}$ \\
\hline $\mathrm{N} 14,1 \mathrm{mg} / \mathrm{mL}$ & $0.59 \pm 0.03^{*}$ & $0.57 \pm 0.03$ & $0.81 \pm 0.07^{*}$ \\
\hline $\mathrm{N} 15,1 \mathrm{mg} / \mathrm{mL}$ & $0.66 \pm 0.03^{*}$ & $0.66 \pm 0.02^{*}$ & $0.44 \pm 0.03^{*}$ \\
\hline $\mathrm{N} 16,1 \mathrm{mg} / \mathrm{mL}$ & $0.63 \pm 0.04^{*}$ & $0.71 \pm 0.03^{*}$ & $0.48 \pm 0.01^{*}$ \\
\hline $\mathrm{N} 17,1 \mathrm{mg} / \mathrm{mL}$ & $0.75 \pm 0.02$ & $0.73 \pm 0.04^{*}$ & $0.49 \pm 0.01^{*}$ \\
\hline $\mathrm{N} 18,1 \mathrm{mg} / \mathrm{mL}$ & $0.49 \pm 0.001^{*}$ & $0.66 \pm 0.05^{*}$ & $0.54 \pm 0.02$ \\
\hline $\mathrm{N} 19,1 \mathrm{mg} / \mathrm{mL}$ & $0.6 \pm 0.04^{*}$ & $0.61 \pm 0.06$ & $0.56 \pm 0.03^{*}$ \\
\hline $\mathrm{N} 20, \mathrm{mg} / \mathrm{mL}$ & $0.5 \pm 0.001^{*}$ & $0.62 \pm 0.01^{*}$ & $0.54 \pm 0.03$ \\
\hline $\mathrm{N} 21,1 \mathrm{mg} / \mathrm{mL}$ & $0.57 \pm 0.03^{*}$ & $0.58 \pm 0.06$ & $1.02 \pm 0.24^{*}$ \\
\hline $\mathrm{N} 22,1 \mathrm{mg} / \mathrm{mL}$ & $0.56 \pm 0.03^{*}$ & $0.89 \pm 0,08^{*}$ & $0.67 \pm 0.16$ \\
\hline Note: $\mathrm{Fx}-\mathrm{ethanol} \mathrm{extract} \mathrm{of} \mathrm{fucoxanthin.}<0.05^{*}$ - with basal. & &
\end{tabular}

All samples of $\gamma$ - $\mathrm{A}_{2}{ }_{2} \mathrm{O}_{3} / \mathrm{PDMS} / \mathrm{Fx}$ composition significantly increased NO production by MSCs and enterocytes compared with control (Table 5). While levels of NO production by EA.Hy926 significantly decreased in the presence of all samples of $\gamma$ - $\mathrm{A}_{2}{ }_{2} \mathrm{O}_{3} / \mathrm{PDMS} / \mathrm{Fx}$ composition $(\mathrm{p}<0.05)$.

The acridine orange/ethidium bromide staining of the splenocytes, thymus, and enterocytes results indicates that the $\gamma-\mathrm{A}_{2}{ }_{2} \mathrm{O}_{3} / \mathrm{PDMS} / \mathrm{Fx}$ composition no have possessed apoptosis to compare with the control (Figure 2).

Polydimethylsiloxane is inert, non-toxic synthetic material used in medicine, cosmetology [16]. Algae/microalgae are sources of a wide spectrum of bioactive molecules include fucoxanthin, with antimicrobial, anti-inflammatory, and antioxidant actions [17, 18].

We observed that fucoxanthin immobilized on porous sorbent on the bases of gammaaluminum oxide and polydimethylsiloxane possess to increasing survival rate and proliferative capacity of naïve and mature immunocytes from female CBA mice after short-term or longterm exposure in vitro. Orally administrated $\gamma-\mathrm{A}_{1}{ }_{2} \mathrm{O}_{3} / \mathrm{PDMS} / \mathrm{Fx}$ composition on the bases of $0.1 \mathrm{~mm}$ and $0.04 \mathrm{~mm}$ particles of the porous sorbent in female CBA mice, and in vitro screening of the all prepared samples of the $\gamma-\mathrm{A}_{1} \mathrm{O}_{3} / \mathrm{PDMS} / \mathrm{Fx}$ composition in common have stimulated proliferative capacity and NO production of enterocytes obtained from jejunum, and cell lines MSCs, and EA.Hy926. While $\gamma-\mathrm{A}_{2} \mathrm{O}_{3} / \mathrm{PDMS} / \mathrm{Fx}$ composition in vitro or in vivo no have significantly change the apoptosis rate of tested cells. 
Figure 2. Apoptosis of splenocytes and thymocytes from female CBA mice in the presence of $\gamma-\mathrm{A}_{2} \mathrm{O}_{3} / \mathrm{PDMS} / \mathrm{Fx}$ composition (x10). (a - splenocytes, control), (b - splenocytes, $\gamma-\mathrm{A}_{2} \mathrm{O}_{3} / \mathrm{PDMS} / \mathrm{Fx}$ composition), (c - thymocytes, control), (d - thymocytes, $\gamma-\mathrm{A}_{2} \mathrm{O}_{3} / \mathrm{PDMS} / \mathrm{Fx}$ composition), (e - enterocytes, control), (f - entreocytes, $\gamma$ $\mathrm{Al}_{2} \mathrm{O}_{3} / \mathrm{PDMS} / \mathrm{Fx}$ composition).

Table 5. Effect of $\gamma-\mathrm{Al}_{2} \mathrm{O}_{3} / \mathrm{PDMS} / \mathrm{Fx}$ composition on mesenchymal stem cells (MSCs), endothelial cell line EA.Hy926 (EA.Hy926), and enterocytes from the jejunum (En) NO production (M+SD, OD).

\begin{tabular}{l|l|l|l}
\hline Parameters & MSCs & EA.Hy926 & En \\
\hline Basal & $9.45 \pm 0.33$ & $13.07 \pm 0.75$ & $9.93 \pm 1.61$ \\
\hline $\begin{array}{l}0.04 \mathrm{~mm} \gamma-\mathrm{Al}_{2} \mathrm{O}_{3} / \mathrm{PDMS}, \\
\mathrm{mg} / \mathrm{mL}\end{array}$ & $20.03 \pm 1.61^{*}$ & $12.67 \pm 3.22$ & $14.21 \pm 1.03^{*}$ \\
\hline $\begin{array}{l}0.1 \mathrm{~mm} \gamma-\mathrm{Al}_{2} \mathrm{O}_{3} / \mathrm{PDMS}, \\
\mathrm{mg} / \mathrm{mL}\end{array}$ & $14.57 \pm 2.89^{*}$ & $13.23 \pm 1.43$ & $18.38 \pm 1.58^{*}$ \\
\hline $\begin{array}{l}0.2-0.8 \mathrm{~mm} \gamma- \\
\mathrm{A}{ }_{2} \mathrm{O}_{3} / \mathrm{PDMS}, \mathrm{mg} / \mathrm{mL}\end{array}$ & $16.87 \pm 3.51^{*}$ & $13.8 \pm 2.06$ & $16.72 \pm 3.57^{*}$ \\
\hline $\mathrm{Fx}, 0.000074 \mathrm{mg} / \mathrm{mL}$ & $11.17 \pm 1.49$ & $10.7 \pm 1.47^{*}$ & $13.4 \pm 0.88^{*}$ \\
\hline Fx, $0.000148 \mathrm{mg} / \mathrm{mL}$ & $19.93 \pm 0.2^{*}$ & $10.2 \pm 0.85^{*}$ & $10.51 \pm 0.75$ \\
\hline \\
https://biointerfaceresearch.com/
\end{tabular}




\begin{tabular}{l|l|l|l}
\hline \multicolumn{2}{l}{} \\
\hline Parameters & MSCs & EA.Hy926 & En \\
\hline $\mathrm{Fx}, 0.00022 \mathrm{mg} / \mathrm{mL}$ & $13.27 \pm 2.25^{*}$ & $14.71 \pm 1.43$ & $11.4 \pm 2.35$ \\
\hline $\mathrm{N} 14, \mathrm{mg} / \mathrm{mL}$ & $16.02 \pm 4.76^{*}$ & $10.47 \pm 2.66$ & $13.41 \pm 1.48^{*}$ \\
\hline $\mathrm{N} 15, \mathrm{mg} / \mathrm{mL}$ & $11.2 \pm 1.01^{*}$ & $7.5 \pm 1.39^{*}$ & $11.07 \pm 0.46$ \\
\hline $\mathrm{N} 16, \mathrm{mg} / \mathrm{mL}$ & $13.93 \pm 6.78$ & $9.51 \pm 1.14^{*}$ & $10.33 \pm 2.65$ \\
\hline $\mathrm{N} 17, \mathrm{mg} / \mathrm{mL}$ & $70.16 \pm 15.5^{*}$ & $6.02 \pm 1.99^{*}$ & $12.43 \pm 2.08$ \\
\hline $\mathrm{N} 18, \mathrm{mg} / \mathrm{mL}$ & $18.7 \pm 2.13^{*}$ & $11.51 \pm 0.5^{*}$ & $11.49 \pm 2.61$ \\
\hline $\mathrm{N} 19, \mathrm{mg} / \mathrm{mL}$ & $24.53 \pm 6.21^{*}$ & $8.65 \pm 0.93^{*}$ & $10.68 \pm 1.5$ \\
\hline $\mathrm{N} 20, \mathrm{mg} / \mathrm{mL}$ & $15.81 \pm 3.25^{*}$ & $10.63 \pm 0.47^{*}$ & $15.33 \pm 2.3 *$ \\
\hline $\mathrm{N} 21, \mathrm{mg} / \mathrm{mL}$ & $15.45 \pm 1.69^{*}$ & $7.77 \pm 2.32^{*}$ & $15.28 \pm 2.66^{*}$ \\
\hline $\mathrm{N} 22, \mathrm{mg} / \mathrm{mL}$ & $13.1 \pm 2.86^{*}$ & $9.25 \pm 2.55^{*}$ & $12.35 \pm 1.66$ \\
\hline Note: Fx - ethanol extract of fucoxanthin, OD - optical density. p<0.05 *with basal.
\end{tabular}

Fucoxanthin reduced the NO and reactive oxygen species production by activated RAW264.7 macrophage cells [19]. Wang obtained that fucoxanthin decreased reactive oxygen species and malondialdehyde in activated by lipopolysaccharide RAW264.7 macrophage cell line [20]. Fucoxanthin possesses to inhibit the viability of gastric cancer SGC7901 cells through the induction of autophagy and apoptosis [21].

\section{Conclusion}

This study demonstrated that the prepared composition of fucoxanthin immobilization on the surface of particle base on gamma-aluminum and polydimethylsiloxane showed not a significant alteration functional properties of splenocytes and thymocytes of female BALB/c mice, enterocytes from the jejunum of CBA/c mice, and MSCs and EA.Hy926 cells.

\section{Funding}

This research was carried out within the framework of government research assignment of RICEL-branch of ICG RAS "Development of methods of molecular profiling and innovative technologies for prediction, early diagnosis, drug and cell therapy of socially significant human diseases of autoimmune, inflammatory and dysmetabolic nature" No. AAAA-A19-119031590016-0 and IBSS RAS "Investigation of the mechanisms of controlling production processes in biotechnological complexes with the aim of developing the scientific foundations for the production of biologically active substances and technical products of marine genesis" No. AAAA-A18-118021350003-6.

\section{Acknowledgments}

The authors thank Dr. C.J. Edgel, Caroline University, USA, for gifted EA.Hy926 cell line and Ekatherina Lykova for article gramma correction.

\section{Conflicts of Interest}

The authors have no conflict of interest to declare.

\section{References}

1. Davinelli, S.; Nielsen, M.E.; Scapagnini, G. Astaxanthin in skin health, repair, and disease: a comprehensive review. Nutrients 2018, 10, https://doi.org/10.3390/nu10040522.

2. Wang, F.; Huang, L.; Gao, B.; Zhang, C. Optimum production conditions, purification, identification, and antioxidant activity of violaxanthin from microalga Eustigmatos cf. polyphem (Eustigmatophyceae). Mar Drugs 2018, 16, https://doi.org/10.3390/md16060190. 
3. Fatima, N.; Kumar, V.; Rawat, B.S.; Jaiswal, K.K. Enhancing algal biomass production and nutrients removal from municipal wastewater via a novel mini photocavity bioreactor. Biointerface Research in Applied Chemistry. 2020, 10, 4710-4720, https://doi.org/10.33263/BRIAC101.714720.

4. Le Goff, M.; Le Ferrec, E.; Mayer, C.; Mimouni, V.; Lagadic-Gossmann, D.; Schoefs, B.; Ulmann, L. Microalgal carotenoids and phytosterols regulate biochemical mechanisms involved in human health and disease prevention. Biochimie 2019, 167, 106-118, https://doi.org/10.1016/j.biochi.2019.09.012.

5. Karpiński, T.M.; Adamczak, A. Fucoxanthin-An Antibacterial Carotenoid. Antioxidants (Basel) 2019, 8, https://doi.org/10.3390/antiox8080239.

6. Zeng, J.; Zhang,Y.; Ruan, J.; Yang, Z.; Wang, C.; Hong, Z.; Zuo, Z. Protective effects of fucoxanthin and fucoxanthinol against tributyltin-induced oxidative stress in HepG2 cells. Environ Sci Pollut Res Int. 2018, 25, 5582-5589, https://doi.org/10.1007/s11356-017-0661-3.

7. Zorofchian Moghadamtousi, S.; Karimian, H.; Khanabdali, R.; Razavi, M.; Firoozinia, M.; Zandi, K.; Abdul Kadir, H. Anticancer and antitumor potential of fucoidan and fucoxanthin, two main metabolites isolated from brown algae. Sci World J. 2014, 2014, https://doi.org/10.1155/2014/768323.

8. Hashimoto, T.; Ozaki, Y.; Taminato, M.; Das, S.K.; Mizuno, M.; Yoshimura, K.; Maoka, T.; Kanazawa, K. The distribution and accumulation of fucoxanthin and its metabolites after oral administration in mice. $\mathrm{Br} J$ Nutr. 2009, 102, 242-8, https://doi.org/10.1017/S0007114508199007.

9. Molina, N.; Morandi, A.C.; Bolin, A.P.; Otton, R. Comparative effect of fucoxanthin and vitamin C on oxidative and functional parameters of human lymphocytes. Int Immunopharmacol. 2014, 22, 41-50, https://doi.org/10.1016/j.intimp.2014.06.026.

10. Zhao, D.; Yu, D.; Kim, M.; Gu, M.Y.; Kim, S.M.; Pan, C.H.; Kim, G.H.; Chung, D. Effects of temperature, light, and pH on the stability of fucoxanthin in an oil-in-water emulsion. Food Chem. 2019, 291, 87-93, https://doi.org/10.1016/j.foodchem.2019.04.002.

11. Sugawara, T.; Baskaran, V.; Tsuzuki, W.; Nagao, A. Brown algae fucoxanthin is hydrolyzed to fucoxanthinol during absorption by Caco-2 human intestinal cells and mice. J Nutr. 2020, 132, 946-51, https://doi.org/10.1093/jn/132.5.946.

12. Korolev, M.A.; Rachkovskaya, L.N.; Konenkov, V.I.; Letyagin, A.Y.; Madonov, P.G. Composition based on aluminum oxide and polydimethylsiloxane - matrix for enhancing drug targeting. Siberian Sci Med J. 2020, 40, 40-46, [In Russian]. https://doi.org/10.15372/SSMJ20200205.

13. Lykov, A.; Surovtseva, M.; Bondarenko, N.; Kim, I.; Taskaeva, Y.; Bgatova, N.; Poveshchenko, P. Erythropoietin and mesenchymal stem cells properties. Biointerface Research in Applied Chemistry 2020, 10, 6197-6207, https://doi.org/10.33263/BRIAC105.61976207.

14. Wang, D.; Ge, S.; Chen, Z.; Song, Y. Evodiamine exert anticancer effects via induction of apoptosis and autophagy and suppresses the migration and invasion of human colon cancer cells. J Buon 2019, 24, 18241829.

15. Lykov, A.; Surovtseva, M.; Rachkovskaya, L. Single wall carbone nanotubes functionalized with composition of $\gamma$-Aluminum oxide and Polydimethylsiloxane properties. IEEE International MultiConference on Engineering, Computer and Information Sciences (SIBIRCON) 2019.

16. Dastjeri, R.; Bahrizadeg, S. Polysiloxane-shield nano-patterned nanolayers: multi-component reactors for photocatalytic purification. Biointerface Research in Applied Chemistry.2018, 8, 3105-3110.

17. Gómez-Zorita, S.; Trepiana, J.; González-Arceo, M.; Aguirre, L.; Milton-Laskibar, I.; González, M.; Eseberri, I.; Fernández-Quintela, A.; Portillo, M.P. Anti-Obesity Effects of Microalgae. Int J Mol Sci. 2019, 21, https://doi.org/10.3390/ijms21010041.

18. Guedes, A.C.; Gião, M.S.; Seabra, R.; Ferreira, A.C.S.; Tamagnini, P.; Moradas-Ferreira, P.; Malcata, F.X. Evaluation of the antioxidant activity of cell extracts from microalgae. Mar Drugs 2013, 11, 1256-70, https://doi.org/10.3390/md11041256.

19. Kong, Z.L.; Sudirman, S.; Hsu, Y.C.; Su, C.Y.; Kuo, H.P. Fucoxanthin-rich brown algae extract improves male reproductive function on streptozotocin-nicotinamide-induced diabetic rat model. Int J Mol Sci. 2019, 20, https://doi.org/10.3390/ijms20184485.

20. Wang,P.T.; Sudirman, S.; Hsieh, M.C.; Hu, J.Y.; Kong, Z.L. Oral supplementation of fucoxanthin-rich brown algae extract ameliorates cisplatin-induced testicular damage in hamsters. Biomed Pharmacother. 2020, 125, https://doi.org/10.1016/j.biopha.2020.109992.

21. Zhu, Y.; Cheng, J.; Min, Z.; Yin, T.; Zhang, R.; Zhang, W.; Hu, L.; Cui, Z.; Gao, C.; Xu, S.; Zhang, C.; Hu $\mathrm{X}$. Effects of fucoxanthin on autophagy and apoptosis in SGC-7901 cells and the mechanism. J Cell Biochem. 2018, 119, 7274-7284, https://doi.org/10.1002/jcb.27022. 